\title{
A NEW SURVEY OF SOURCES OF THE AMAZON
}

B. Janský: A New Survey of Sources of the Amazon. Geografie - Sborník ČGS, 105, 2, pp. 129 - 140 (2000). From the 16th of June to the 1st of July 1999 the expedition Hatun Mayu (meaning Big River in Quechua) explored the source area of the Apurímac River in southern Peru. The seven member expedition was lead by the author of this article, a member of the Faculty of Science, Charles University, Prague. The aim of the group was to measure the lenght of the main source of the Apurimac River currently considered by most hydrologists as the longest source segment of the Amazon. In addition, the expedition members maesured flows and altitudes in order to create the lenghtwise profile of the Río Carhuasanta stream.

KEY WORDS: Amazon - Apurímac River - Río Carhuasanta stream - expedition Hatun Mayu.

\section{An historical introduction to the location of the sources of the Amazon}

1.1. Samuel Fritz - the Bohemian Jesuit and author of the map of the Amazon

One of strong motivations for our expedition to explore the sources of the Amazon was the achievements of a little known Jesuit of Bohemian origin, Samuel Fritz, who is known mainly in the Hispanic world as author of the first serious map of the Amazon.

After finishing his studies at the Faculty of Arts of Charles University and at St. Wenceslas seminary, Fritz entered the Jesuit order. In 1683 he was sent together with J. V. Richter and J. Burgr on a mission in the West Indies. Via Genoa, Seville, Cadiz and the Canary Islands, they arrived at the island of Martinique and then went on to Cartagena in Columbia. After a difficult journey up the Magdalena River, they progressively moved, via the Colombian towns of Popayán and Pasto to Quito in Equador, down the rivers of Pastaza and Napo to the main course of the Amazon. Then they went upstream to the mouth of the Huallaga River and to the seat of a Spanish mission in the settlement La Laguna.

Later Fritz visited the Omanguas and Yurimanguas tribes in the lower course of the Maranon River and the Ybanons and Aizuars tribes at the mouth of Rio Negro. During one of his expeditions in the region of the Amazon he was captured by the Portuguese and imprisoned at the Portuguese Jesuit College in Pará at the mouth of the Amazon for 18 months. When he finally returned to his Spanish mission in 1691 , he had mapped the various tributaries, islands, Indian settlements of the Amazon, along his $1300 \mathrm{~km}$ journey. After visiting the Spanish viceroy in Lima, he stopped at the upper course of the Marañon River and identified its sources in the mountain Lake of Lauricocha. 


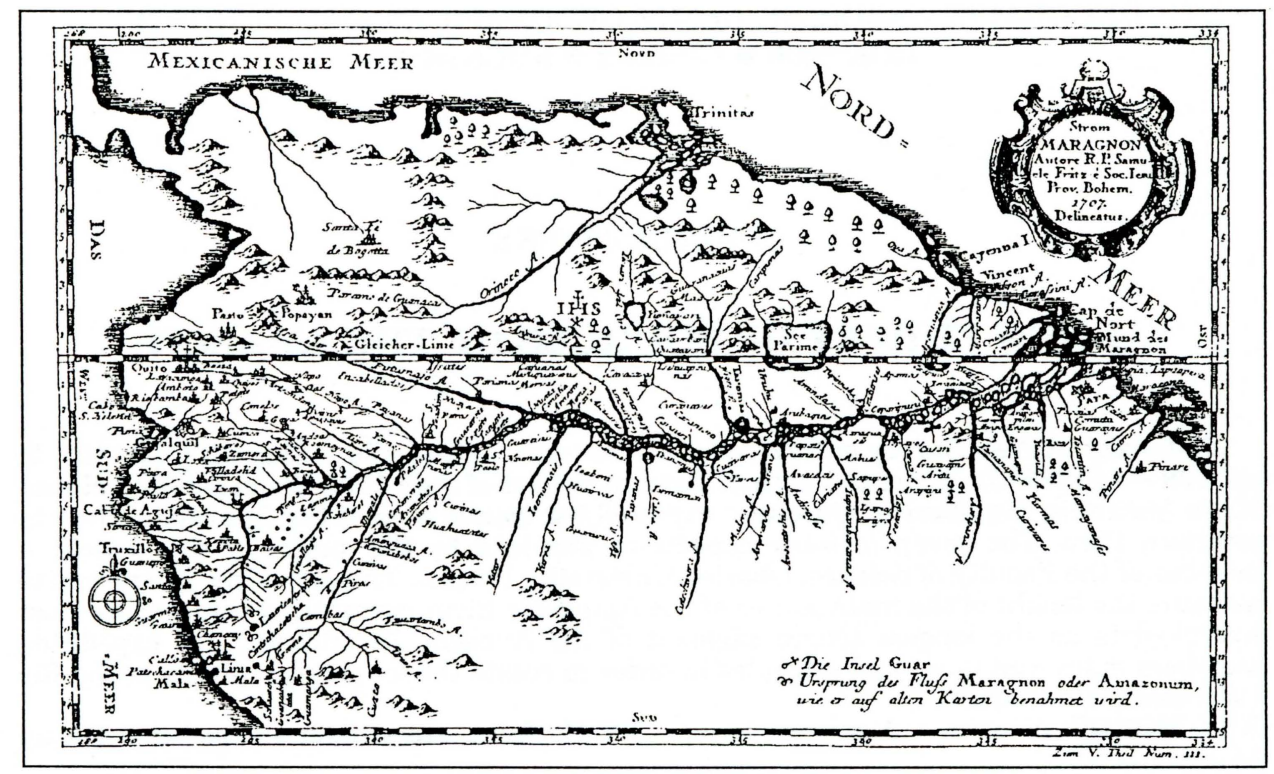

Fig. 1 - The map of the Bohemian jesuit Samuel Fritz from 1707

Even now this place is indicated as the source area of the largest river of the planet (see for example the New Encyclopaedia Britannica, 1998).

Samuel Fritz was the first human who explored and traveled the entire main course of the Amazon from the sources of the Marañon to its mouth. In 1707, he drew the second map of the river (the first was drawn by Guillermo Sanson), which was much more accurate than any existing one. The map, incredibly precise given when it was done, was drawn only with a protractor.

\subsection{Changing opinions of the sources of the Amazon}

Until the 1950's, the Marañon River was considered the source segment of the Amazon. Nearly 250 years after publication of the map of the Bohemian Jesuit Samuel Fritz in 1707, his identification of the Amazon source in Lake Lauricocha in Central Cordillera in the Peruvian Andes was still valid.

In the 1950's however, some data were published affirming that a second source stream of the Amazon, the Ucayali, was considerably longer than the Marañon River. In contrast to the earlier period when lengths of streams were established using maps at the scale of 1:2 500000 or 1:1 000000 , more detailed maps at scales of 1:200 000 or 1:100 000 were now used. This enabled more accurate consideration of important river meanders and thus streams were found to be considerably longer.

In 1953, the French explorer Michel Perrin confirmed the conclusion of a Peruvian colonel, Gerardo Dianderas, that the longest source stream of the Ucayali River was the Río Apurímac measuring the source from the foot of the Huagra Mountains in the Cordillera Chila in southern Peru (department of Arequipa), to the north-west from the village of Cailloma. This contention was accepted by geographers for more than 15 years and for a long time it also appeared in Czech geography textbooks. This source was also mentioned by Rostislav Netopil in his publication, "Hydrology of continents" (1972). 
Tab. 1 - Survey of opinions on the location of the Amazon sources

\begin{tabular}{|l|c|l|}
\hline Author & Year & Source \\
\hline S. J. Santos García & 1935 & Laguna Vilafro \\
Michel Perrin & 1953 & Cerro Huagra \\
plk. Gerardo Diánderas & 1953 & Cerro Huagra - Río Monigote \\
Helen a Frank Schreider & 1968 & Laguna Vilafro \\
Nicholas Asheshov & 1969 & Nevado Minaspata \\
Carlos Peńaherrera del Aguila & 1969 & Nevado Mismi - Carhuasanta valley \\
Loren Mc Intyre & 1971 & Nevado Choquecorao \\
Walter Bonatti & 1978 & Río Huarajo \\
Jean Michel Cousteau & 1982 & Nevado Choquecorao \\
Jacek Palkiewicz, & 1997 & Nevado Quehuisha - Apacheta valley \\
Zaniel I. Novoa Goicochea & & \\
\hline
\end{tabular}

Source: Goicochea, Z. I. N. (1997), adapted

In $1968 \mathrm{Mr}$. and Mrs. Schreider designated Lake Vilafro as the source area of the Apurimac River, where Río Santiago has its source and which is situated about $11 \mathrm{~km}$ east from the village of Cailloma.

A year later the English journalist Nicholas Asheshov who visited the Cerro Minaspata summit (about $30 \mathrm{~km}$ south-west of Cailloma) together with the parachutist and adventurer John Ridgway confirmed that the source segment of Río Apurímac was situated exactly at that place.

In the same year, the eminent Peruvian geographer, Carlos Peñaherrera del Aguila, published a monograph entitled, "Geografía general del Perú". His published data were based on results of the research done by the Instituto Geográfico Nacional in Lima. The source of the Río Apurímac was given as Quebrada Carhuasanta at the northern foot of the Nevado Mismi Mountain and that source is precisely located with geographic coordinates $-71^{\circ} 40^{\prime} 36^{\prime \prime}$ of west longitude and $15^{\circ} 30^{\prime} 49^{\prime \prime}$ of south latitude.

In 1971 an expedition was organized under the auspices of the National Geographic Society and the International Geodetical Service. It was led by the photographer Loren McIntyre who was accompanied by the mountaineer Richard Brandshaw and a geographer Víctor Tupa. The aim of the expedition was to confirm the hypothesis of American cartographers that the Río Carhuasanta was the longest source stream of the Amazon. McIntyre announced that the most remote source originates at a small lake at the foot of Nevado Choquecorao Mountain, generally called Nevado Mismi. This place is situated less than $2 \mathrm{~km}$ from the source identified by Dr. Peñaherrera.

Other expeditions followed. In 1978 Walter Bonatti agreed with the finding of M. Perrin and designated as the source segment of the Amazon the Río Huarajo with its source at the foot of Cerro Huagra. In preparing a film about the Amazon, Jean Michel Cousteau visited the region of Southern Peru in 1982 and accepted the findings of McIntyre put forth theory about localization of the 11 years earlier.

The last expedition to attemt to find the source of the largest river of the planet took place in 1996. An international expedition led by the Polish adventurer Jacek Palkiewicz included two Russians (the glaciologist S. 
Tab. 2 - Data regarding the length of the Amazon

\begin{tabular}{|l|l|l|c|}
\hline Name & Country & Year & Lenght (km) \\
\hline O. H. Walkey & Great Britain & 1949 & 6517 \\
E. J. Devroey & USA & 1950 & 6595 \\
C. Peńaherrera & Peru & 1969 & 6762 \\
J. Marcinek & G.D.R. & 1978 & 6510 \\
IIAP - Iquitos* & Peru & 1980 & 6885 \\
J. Cousteau & France & 1984 & 7025 \\
J. C. P. Grande & Brazil & 1985 & 6571 \\
IGN - Perú** & Peru & 1989 & 6762 \\
J. Marcinek, E. Rosenkranz & Germany & 1996 & 6516 \\
P. Martini, J. Wagner & Brazil & 1996 & 7062 \\
\hline
\end{tabular}

* Instituto para la Investigacion de la Amazonía Peruana

** Instituto Geografico Nacional del Perú

Ushnurtsev and the geographer R. Chayrutdinova from the Russian Academy of Sciences), four Peruvians (Z. N. Goicocheou from the Pontifica Universidad Católica del Perú, the hydrographers G. Faura and P. Rojas and the mountaineer J. L. T. Velasco) and the Italian adventurer T. Grego. The expedition located a new source segment of the Apurímac River the Río Apacheta, which had its source at $5170 \mathrm{~m}$ at the foot of the Nevado Quehuisha Mountain in the Cordillera Chila range in the western Peruvian Andes. The authors consider this stream to be the longest and the most watery source. It originates at the highest altitude of all the identified source segments of the Apurímac River (tab. 1, 2).

\section{Preparation of the current expedition and study methods}

The author of this article began preparations for the expedition in 1990 . He gave a series of lectures on hydrology and general physical geography at two Peruvian universities - Universidad Nacional Mayor de San Marcos in Lima and Universidad Nacional San Antonio Abad del Cuzco. He obtained from the then dean of the Faculty of Geography in Lima, Prof. Dr. Carlos Peñaherrera, his monograph Geografía general del Perú in which he published the theory that the source area of the Amazon was located at the northern foot of the Nevado Mismi summit in the Quebrada Carhuasanta (Departamento Artequipa). Although the author of the monograph had never visited this region, his hypothesis was based on data found on maps of the National Geographical Institute in Lima.

At that time the idea of preparing field research in this region arose. Literature, maps and aerial photographs of the region in question were gathered. In 1995, the author visited the Carhuasanta Valley with a geographical expedition from the Faculty of Science, Charles University, and proceeded to conduct a preliminary survey of the region. By 1999 sufficient financial resources and equipment necessary for fieldwork were gathered. 
Before the expedition departed an analysis of the hydrographical network of the upper part of the Río Apurímac source area was completed using topographical maps at the scale 1:100 000 (sheets Cailloma 31-6 and Chivay 32 -s). The lengths of all the streams that had been at any time designed as sources of the Amazon were measured up to the confluence of Río Santiago and Río Hornillos, situated at about $14.5 \mathrm{~km}$ east of the village of Cailloma, where the Río Apurimac begins. At the same time, aerial photographs at the scale 1:50 000 depicting the main ridge of the Cordillera de Chila Mountains and the upper course of Río Lloqueta with its four principal sources were studied.

Following instruments were used for field research: a laser range finder, LEM TM 30 (produced by Jenoptic, Germany) with tripod; special height gauges, ALTI PLUS 2 and BARIGO; a hydrometric propeller, C 20 (produced by OTT Messtechnik, Kempten, Germany).

\section{Geographical location and natural conditions of the region}

The study region is a part the Cordillera Occidental mountain range in the southern Peruvian Andes. The source area of the Apurímac River is situated on northern slopes of the main ridge of the Cordillera de Chila extending between $15^{\circ} 04^{\prime} 20^{\prime \prime}$ and $15^{\circ} 32^{\prime} 19^{\prime \prime}$ of south latitude and $71^{\circ} 366^{\prime} 38^{\prime \prime}$ and $71^{\circ} 54^{\prime} 00^{\prime \prime}$ of west longitude.

Administratively, the region belongs to the districts of Lari and Cailloma in Cailloma province, which is a part of the department of Arequipa in the south of Peru. The mining village of Cailloma, the starting point of the expedition, lies about $140 \mathrm{~km}$ north from Arequipa. The distance can be traveled by bus on gravel roads in about 12 hours, while a good cross-country vehicle can manage it in eight hours.

\subsection{Georelief}

The study region is a complex area of mountain ranges, river valleys, plateaus and a large intermontane basin. In the south the arc of the main ridge of the Cordillera de Chila Mountains with its highest summits (from the southeast to the northwest) rises: Mismi (5 $597 \mathrm{~m}$ ), Choquecorao, Hueracahua, Quehuisha, Calomorco, Ccaccansa, Jatunpila (5 $437 \mathrm{~m}$ ), Surihuiri (5 $556 \mathrm{~m}$ ) and Inaspata. At the same time the forms the main continental water-shed between the Atlantic and the Pacific drainage areas that is between the catchment area of the Apurímac River a tributary of the Amazon, and the Río Colca catchment area that, as Río Camaná (in its middle course, called Río Majes) flows into the Pacific Ocean. The northern and the western slopes of the mountains are not as steep as their southern slopes where the canyon of Río Colca has been deepened into unsolidified volcanic tuffs. The maximum height difference between the Río Lloqueta Valley in the north and the ridge line of the mountain range is 700 to $800 \mathrm{~m}$, while the Río Colca Valley on the southern slope is incised to a depth of 2200 to $2500 \mathrm{~m}$. After a distance of $30 \mathrm{~km}$, the depth of the Colca canyon reaches $3200 \mathrm{~m}$.

From the viewpoint of the geological stratigraphy, rocks of both sedimentary and volcanic origin are dominant, dating from the Middle Tertiary to the present. In the Cordillera de Chila range, in the source area of Río Lloqueta and at the watershed with Río Ancollagua, rocks of Middle Tertiary appear at the surface and form the stratigraphic unit Tacaza. In its 
upper part, which is up to $800 \mathrm{~m}$ thick, this formation consists of grey basaltic or ryolite lavas with frequent fissures filled by volcanic tuffs. In the deep cuts of rivers (for instance, below the confluence of both source streams of the Carhuasanta), there is frequently found a denuded thick lacustrinal formation (up to $1000 \mathrm{~m}$, in Goicochea, Z.I.N., 1997) with laminarly arranged greenish, locally violet coloured sands and frequent fragments of volcanic rocks. In the upper part of the formation, lavas are clearly predominant tuffs and conglomerates with blocs ranging in size from 0.5 to $10 \mathrm{~m}$, are dominant in the deeper areas. The pleistocene is represented by the 20 to $150 \mathrm{~m}$ thick Barroso formation, consisting of greyish andesites and porphyries under the form of lava nappes or vaults. There however are also typical stratovolcanos with remnants of original parasitic volcanic cones.

The major part of the catchment area of the Río Apurímac's upper course is nevertheless formed by a large graded area and mainly by the very large Cailloma basin (Depresión de Cailloma). Pleistocene loams, sands and gravels, accumulated in the form of alluvia, glaciofluvial sediments and moraines fill the basin. Among the recent sediments, there are unsolidified sands, gravels and loams in the form of alluvial cones, fluvial alluvia, debris cones, and unsolidified material from stone and mud flows (huaycos).

Geomorphologic processes are also influenced by the extreme climatic conditions, the huge accumulation of snow, and the occurrence of glaciers. Under these conditions, numerous lakes of glacial origin were formed (including laguna "Bohemia"). Locally there is also permafrost that in summer (December-March) periodically melts at the surface.

\subsection{Climatic conditions}

Climatic conditions are mainly influenced by the high altitude which varies from $4140 \mathrm{~m}$ a. s. l. at the confluence of the Río Santiago and Río Hornillos (the place of origin of Río Apurímac) and $4319 \mathrm{~m}$ (Cailloma village) and up to the ridge of Cordillera de Chila reaching altitudes of about $5500 \mathrm{~m}$. The region is also isolated from the impacts of the Pacific Ocean and the Amazon Basin. During the three winter months (June - August) the mean monthly temperatures are below $0{ }^{\circ} \mathrm{C}$, although night temperatures drop below $-20{ }^{\circ} \mathrm{C}$. During the expedition, the lowest temperature registered at the bank of Río Challamayo was $-18{ }^{\circ} \mathrm{C}$. In the warmest months (January, February), monthly averages reach about 6 to $7{ }^{\circ} \mathrm{C}$. The nearest permanent climatic station in Yauri (3 $915 \mathrm{~m}$ a.s.l.), situated about $50 \mathrm{~km}$ north-east, registers a mean annual temperature of $3.5^{\circ} \mathrm{C}$. The warmest month is January with an average temperature of $7{ }^{\circ} \mathrm{C}$ whereas the coldest is July $\left(-0.6{ }^{\circ} \mathrm{C}\right)$. Average local rainfall is $662.3 \mathrm{~mm}$. Although in the study region of the source area of Río Apurímac temperatures are slightly lower, the total annual rainfall at higher altitudes amounts to as much as $1000 \mathrm{~mm}$. The major part of the precipitation falls from November to March, while in January and February the region is covered by snow. The period, May-September, is characterized by low rainfall.

As in the majority of the mountains of the Peruvian Andes, glaciation of the Cordillera de Chila massif is of a local character. Because of the high altitude and the isolation from the ocean, there are favourable temperature conditions for the formation of glaciers. The decisive process in this case is the quantity of fallen snow. Glaciers and long-term snow cover encompass an area of $33.89 \mathrm{~km}^{2}$. The lower limit of long-term snow cover lies on northern slopes of 
the main ridge at about $5300 \mathrm{~m}$ a. s. 1 . The majority of the 87 glaciers fill cirques, from which descend short slope or valley glaciers. According to the inventory of glaciers in Peru, published in the Atlas del Perú (1989), the total volume of glacier mass in Cordillera de Chila is $0.578 \mathrm{~km}^{3}$, or about $1.03 \%$ of the volume of all the glaciers in Peru.

In the source area of the Apurimac River glaciers, long-term snow cover and permafrost create very favourable hydrological conditions for streams, supplying water, especially in the summer months (from November to March). Accumulation of melt water in source areas influnces vegetation grouth as well. Especially large green cushions called champa (Distichia muscoides) absorb enormous quantities of water. They are made up of tightly tangled stems, leaves and roots of different species of trailing plants forming a sort of oval carpet. Depending on water content or the presence of permafrost, the surface may be months hard or, on the contrary, very soft. Champa and other plant species form, by successive growth and decay of their lower parts, huge (up to $10 \mathrm{~m}$ thick) layers of humolites in the source area of Río Carhuasanta. Among the numerous vegetal species are especially grasses: ichu (Stipa ichu), sora (Calamagrostis eminens), chilhuar (Festuca orthophylla), tisna (Stipa obtusa). An important nutrient for herds of Tylopodous (lamas, alpacas and vicunas) is the low shrub tola (also called llianta, Lepidophyllum rigidum) that, once dried, is also used as fuel for fires. A very dominant plant on mountain slopes at altitudes higher than $4500 \mathrm{~m}$ is yarita (also called yareta, Azorella yareta) often forming large, several metres high cushions. Becouse of its high content of resins, it is dried and, used as fuel.

\section{Hydrographical and hydrological conditions of the source area of the Río Apurímac}

Before the expedition began, a hydrographical analysis of the river network of the upper course of Río Apurímac and of all its sources was done using topographical maps from the National Geographical Institute in Lima

Tab. 3 - Results of the measurement of the lengths of streams in the source area of Río Apurímac (measured on topographic maps at a scale 1:100 000, IGN, Lima Peru)

\begin{tabular}{|l|l|c|}
\hline Source & Source stream & Lenght* (km) \\
\hline Laguna Vilafro & Quebrada Huancane - R. Santiago & 35.3 \\
Cerro Huagra & Río Huarajo - R. Santiago & 37.9 \\
Cerro Minaspata & $\begin{array}{l}\text { Quebrada Yanacocha - R. Ancollagua - } \\
\text { R. Challamayo - R. Hornillos }\end{array}$ & $55.5^{* *}$ \\
Nevado Mismi & $\begin{array}{l}\text { Laguna "Bohemia" - Q. Carhuasanta - } \\
\text { R. Lloqueta - R. Challamayo - R. Hornillos } \\
\text { Nevado Quehuisha }\end{array}$ & $\begin{array}{l}\text { Q. Apacheta - R. Lloqueta - R. Challamayo - } \\
\text { R. Hornillos }\end{array}$ \\
\hline
\end{tabular}

* lengths measured from the source to the confluence of Río Santiago and Río Hornillos where the Río Apurímac begins

** when measured via the artificial canal (i.e. via Lago Parihuana - Río Challamayo -Lago Huarjuarco - Río Huarhuarco - Río Santiago) all lengths are 9.1 km longer 


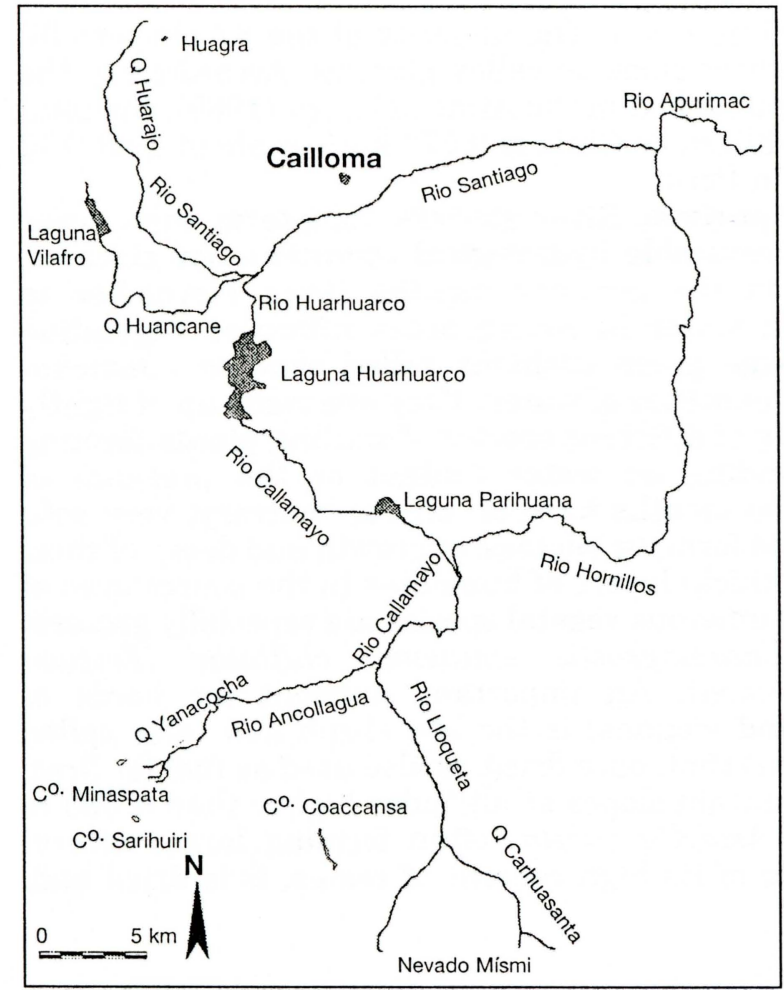

Fig. 2 - Region of Source Of Rio Apurimac

Nacional) and aerial photographs of the upper course of Río Lloqueta. On the basis of these data the lengths of all the sources designated in the past as source segments of the Amazon were established.

The results of the measurements explicitly confirmed the initial hypothesis that the sources of the longest source stream of the Apurimac River must be found at the foot of the Nevado Mismi and Nevado Quehuisha massifs, where Río Lloqueta originates at the confluence of four source streams. Although in 1966 an international expedition headed by $J$. Palkiewicz designated the valley of Quebrada Apacheta as the main source, our measurements favoured the neighbouring valley - the Quebrada Carhuasanta (see Tab. 3).

In addition to measuring the lengths of the natural river beds, a remeasurement of the river network was done in the region Laguna Parihuana and Laguna Huarhuarco lakes where, in the past, an essential change of drainage occurred as a result of due to human intervention. This information originates with one of the participants of the Czechoslovak watercraft expedition in 1982, ing. Bobák, and also from the literature (see Asheshov 1970). It was also confirmed during our visit in the area. Some time after 1940 a mining engineer from Cailloma Mining Company dug a canal separating from the riverbed of Río Challamayo to feed the Parihuana lake. The work continued at the outflow from the lake, where a $2.7 \mathrm{~km}$ long underground tunnel was dug. Later on, a small dam and an aqueduct were built to bring water to two water power plants supplying local copper and silver mines. According to our measurements, this intervention extended the source segment of the Río Apurímac by $9.1 \mathrm{~km}$ compared with the natural riverbed via Río Hornillos.

Studying the results of the international expedition of 1996 confirmed that it is essential to carry out detailed measurements with the help of the latest instruments. Lengths were maesured with the latest version of a laser range finder, LEM TM 30, produced by Jenoptik and enabling measurements within a milimetre. We thus excluded the use of GPS that are not as precise. Given our work great doubt is shed on the results of expeditions noted above that used this instrument for measuring lengths. 
4.1. Results of the field survey in the Carhuasanta Valley

Measurements works started in the base camp of the expedition at the confluence of both principal sources of the Río Lloqueta - that is the Carhuasanta and Apacheta, at an altitude of $4781 \mathrm{~m}$. When measuring, we proceeded along the main river bed so as to record all meanders. Up to the confluence of both principal sources of the Carhuasanta (5 $026 \mathrm{~m}$ a. s. 1.), the stream measured $6521.1 \mathrm{~m}$ descending $245 \mathrm{~m}$ and with a mean inclination of $3.76 \%$.

The left source of Carhuasanta originates from a glacier lake indicated on maps as Laguna with its surface at the altitude of $5233 \mathrm{~m}$. The geographical coordinates of this sources are the following: $15^{\circ} 30^{\prime} 33^{\prime \prime}$ of south latitude and $71^{\circ} 41^{\prime} 34^{\prime \prime}$ of west longitude. On June 23, 1999 the minimal outflow of the lake was $9 \mathrm{l} / \mathrm{s}$. This water flowed over a rock step at $5228 \mathrm{~m}$ a. $\mathrm{s} .1$. and in the form of a fine spray fell onto a firn field at $5212 \mathrm{~m}$. The upper edge of this small waterfall was only $15.5 \mathrm{~m}$ from the outflow of the lake. The total length of Carhuasanta from the left source equals $7872.9 \mathrm{~m}$. The left source has up to the confluence with the right source, a drop of $186 \mathrm{~m}$ with a mean inclination of $13.76 \%$.

The right source of Carhuasanta arises as a huge fissure spring under a $36 \mathrm{~m}$ high vertical rock wall at $5238 \mathrm{~m}$ (the upper edge of the step is at an altitude of $5274 \mathrm{~m}$ ). The geographical coordinates of this source are $15^{\circ} 30^{\prime} 7^{\prime \prime}$ south latitude and $71^{\circ} 41^{\prime} 13^{\prime \prime}$ west longitude. The volume of the spring the day on June 24, 1999 was $20 \mathrm{l} / \mathrm{s}$. The rock wall is penetrated by a vertical fault zone interfering against the slope. It is certain that the source is fed by melting snow and by the glacier at the foot of Mismi above the rock step and that the water penetrates into largely open fissures. The total length of Carhuasanta from its right source is $7799.3 \mathrm{~m}$. It has, up to the confluence with the left source, a drop of $212 \mathrm{~m}$ with a mean inclination of $16.59 \%$.

During the field work, flow was measured in three streams. In Río Lloqueta, it reached $535.9 \mathrm{l} / \mathrm{s}$ on June 21 at 13 o'clock above the confluence with Río Ancollagua (altitude $4721 \mathrm{~m}$, the width of the riverbed was $6.2 \mathrm{~m}$, water temperature $3^{\circ} \mathrm{C}$ ). The flow of Río Apacheta was $205.9 \mathrm{l} / \mathrm{s}$ above the confluence with the Río Carhuasanta (altitude $4788 \mathrm{~m}$, the width of the riverbed $2.2 \mathrm{~m}$, water temperature $1^{\circ} \mathrm{C}$ ). The flow of Río Carhuasanta was $168.6 \mathrm{l} / \mathrm{s}$ above the confluence with Río Apacheta (altitude $4799 \mathrm{~m}$, width of the riverbed $2.75 \mathrm{~m}$, water temperature $1{ }^{\circ} \mathrm{C}$ ). The second and the third measurements were taken under stable conditions at 9 , respectively 9.30 o'clock on June 24 with the help of a hydrometric propeller, C 20 , produced by OTT.

\section{Conclusion}

When determining the main sources of a stream, hydrographic practice takes into consideration the following criteria: length of the course together with the altitude of the source, the expanse of water area, flow, levelling of lengthwise profile and the evolution age of the river bed. With a view to these criteria we can state the following:

1. The Río Carhuasanta is the main source of the Río Apurímac and thus also of the Amazon. This conclusion is verified by the results of our field and 
cartometric measurements. The total length of the source segment from the left source of the Carhuasanta in the glacier Lake of Laguna down to the beginning of the Apurímac River (confluence of Río Santiago and Río Hornillos) is $59,573 \mathrm{~km}$.

2. The sources of the Río Carhuasanta are situated at the highest altitudes of all the sources described by previous expeditions - $5238 \mathrm{~m}$ (the right source) and, $5233 \mathrm{~m}$ (the left source).

3. The largest catchment area of all the sources of the Río Lloqueta is that of the Carhuasanta $\left(19.6 \mathrm{~km}^{2}\right.$, compared to Sillanque $14.1 \mathrm{~km}^{2}$, Apacheta $14.1 \mathrm{~km}^{2}$, Ccaccansa $8.8 \mathrm{~km}^{2}$ ), see also the data given by Goicochea, Z.I.N. (1997).

4. The Río Apacheta is characterised by a greater flow (205.9 l/s than the Río Carhuasanta $168.6 \mathrm{l} / \mathrm{s}$ ).

5. The artificial canal extending from the Río Challamayo and feeding Parihuana and Huarhuarco lakes elongates the source segment of the Río Apurímac by $9.1 \mathrm{~km}$. The natural river bed is nevertheless the Río TYornillos.

6. The longest source segment of the Amazon has the following course: sources of the Río Carhuasanta - R. Lloqueta - R. Challamayo - R. Hornillos - at its confluence with R. Santiago begins the Río Apurímac. At its lower course, it changes its name to the $R$. Ene and then to the $R$. Tambo. At its confluence with the R. Urubamba the Ucayali begins and after its confluence with Marañon, the Amazon.

In spite of the valuable results reached by the expedition this work is really a further stage in the study of the source area of the largest stream on the Earth. We are convinced that the same methods used here in the case of the Carhuasanta must be used for measuring other source streams, mainly the Río Apacheta and the Río Ccaccansa. Only then can the discussion about the source of the Amazon be closed.

\section{Literature:}

ASHESHOV, N. (1970): The real source of the Amazon is a glacier on a remote mountain called Minaspata. Peruvian Times, October 30.

ATLAS DEL PERÚ (1989): Inventario de Glaciares del Perú. Hidrándina S.A. Unidad de Glaciología e Hidrología. Huaráz, Peru.

CARDICH, A. (1959): Leyenda y verdad sobre el origen del Río Amazonas. Universidad de Buenos Aires, Argentina.

GOICOCHEA, Z. I. NOVOA (1997): El origen del Río Amazonas. Pontificia Universidad Catolica del Peru. Lima, Peru.

EDYM (1992): Descubrimiento del Río de las Amazonas. De la Colección Vida Amazonas. Estudios, Ediciones y Medios (EDYM). Madrid, Španělsko.

FAURA GAIG, G. (1964): Los Ríos de la Amazonía Peruana. Imp. del Colegio Militar Leoncio Prado. Lima, Peru.

HIDRANDINA, S.A. (Inventario de Glaciares del Perú. Unidad de Glaciología e Hidrología, CONCYTEC. Huaraz, Peru.

JANSKÝ, B. (1997): Samuel Fritz - Bohemian Jesuit and author of a map of the Amazon. Acta Universitatis Carolinae - Geographica, XXXII, No. 2, pp. 149-154.

JANSKÝ, B. (1991): Las ocho regiones naturales del Perú. Acta Universitatis Carolinae Geographica, XXVI, No. 1, pp. 17-35.

MARCINEK, J. (1978): Das Wasser des Festlandes. Justus Perthes Verlag, 3. Aufl. Gotha, D.D.R.

MAP.CINEK, J., ROSENKRANZ, E. (1996): Das Wasser der Erde. Justus Perthes Verlag. Gotha, B.R.D. 
MARTINI, P., WAGNER, J. (1996): Depicting the headwater of the Amazon River - Trough the use of remote sensing data. Brazilian National Institute of Space Research - INPE. Săo Paulo, Brasil.

McINTYRE, L. (1972): The Amazon - Mightiest of Rivers. National Geographic Magazine. Washington, USA.

PALKIEWICZ, J. (1997): Towards the origin - In search of the Amazon, the most extraordinary river on Earth. El Dorado. Lima, Peru.

PENAAHERRERA DEL AGUILA, C. (1969): Geografía General del Perú. Editorial Auzonia. Lima, Peru.

PULGAR VIDAL, J. (1987): Geografía del Perú. Las ocho regiones naturales. PEISA. Lima, Peru.

RAIMONDI, A. (1965): El Perú. Universidad National de Ingenería. Editores Técnicos Asociados. Lima, Peru.

THE NEW ENCYKLOPAEDIA BRITANNICA (1998): Macropaedia. No. 27, p. 706. The University of Chicago, USA.

\section{Shrnutí}

\section{NOVÉ VYMĚRENÍ PRAMEN Ů AMAZONKY}

Ve druhé polovině června 1999 se uskutečnila expedice Hatun Mayu (kečuánsky „Velká řka“), která směřovala do pramenné oblasti řeky Apurímac na jihu Peru. Sedmičlennou výpravu vedl autor článku, který společně s dalším organizátorem akce, fotografem a kameramanem Vladimírem Šimkem, navštívil toto území již při expedici Peru 95. Ještě před cestou bylo provedeno měření délek toků jednotlivých zdrojnic řeky Apurímac na leteckých snímcích a topografických mapách v měřítku 1:100 000. U předem vytypované hlavní zdrojnice Río Carhuasanta byla pak v terénu detailně změřena její délka a stanoveny nadmořské výšky, které umožnily vynesení podélného profilu toku. Rovněž se uskutečnilo měření průtoků vody na hlavních pramenných tocích Río Apurímac.

Jedním z motivů expedice byla postava jezuity českého původu Samuela Fritze, který se především v hispánském světě proslavil jako autor první kvalitní mapy Amazonky. Fritz, narozený v Trutnově, postupně absolvoval Filosofickou fakultu Karlovy Univerzity, Svatováclavský seminář v Praze a poté vstoupil do jezuitského řádu. V roce 1683 byl spolu s J.V. Richterem a J. Burgrem vyslán do misijní služby v tehdejší Západní Indii. Po dlouhé cestě přes italský Janov, španělskou Sevillu, Cádiz, Kanárské ostrovy, ostrov Martinique, kolumbijský přístav Cartagenu a strastiplném putování proti proudu řeky Magdalena, andská města Popayán, Pasto a Quito, splutí řeky Pastaza se dostali až na hlavní tok Amazonky. Po jejím proudu se vydali k ústí Huallagy do sídla španělské misie La Laguna. V dalších letech Fritz postupně navštívil několik indiánských kmenů na dolním Marañonu a při ústí Rio Negro. Po zajetí Portugalci byl 18 měsíců vězněn v portugalské jezuitské koleji $\mathrm{Pa}$ rá př̀i ústí Amazonky. Po propuštění v roce 1691 mapoval během $1300 \mathrm{~km}$ dlouhé plavby přítoky Amazonky, řiční ostrovy i jednotlivé indiánské osady. V roce 1693 navštívil španělského místokrále v Limě a na zpáteční cestě popsal prameny Amazonky v horském jezeře Lauricocha. Jako pramennou oblast největšího veletoku na Zemi udává tento region dodnes New Encyclopaedia Britannica (1998). Fritzova mapa Amazonky z r. 1707 byla v pořadí druhá na světě (po Guillermo Sansonovi), avšak mnohem dokonalejší.

Do 50. let 20. stol. byl za pramenný úsek Amazonky považován Marañon, tzn. více než 250 let platila teorie S. Fritze. Za pomoci map větších měřítek bylo zjištěno, že druhá zdrojnice Amazonky - Ucayali je výrazně delší než Marañon, a tak mnohé expedice zamírili poté do pramenné oblasti Río Apurímac, nejdelší zdrojnice Ucayali. Od roku 1953, kdy byl za pramen největší řeky světa označen vrchol Cerro Huagra v pohoří Cordillera Chila na jihu Peruánských And, se uskutečnilo několik výprav, které se snažily přesně určit místo pramene (viz tab. 1). V souvislosti $\mathrm{s}$ tím se také objevovaly $\mathrm{v}$ literatuře odlišné údaje o délce Amazonky (viz tab. 2).

Po revizi údajů všech dosavadních výprav a detailních kartometrických měřeních na topografických mapách a leteckých snímcích se autor článku vrátil k původní teorii prof. dr. Carlose Peñaherrery z roku 1969. Cílem expedice bylo tedy potvrdit na základě výsledků terénních měření, že nejdelší zdrojnicí řeky Apurímac a tedy Amazonky je Quebrada Carhuasanta v departamentu Arequipa na jihu Peru. 
Součástí tohoto článku je stanovení přesné geografické lokalizace pramenů a popis př́rodních podmínek regionu hlavního hřebene a severního úpatí pohoři Cordillera Chila, který je součástí pásma Cordillera Occidental jižních Peruánských And. Pozornost je přitom věnována charakteristikám georeliéfu, rozsahu zalednění, klimatickým a vegetačním poměrům.

Detailní analýze jsou podrobeny hydrografické poměry pramenné oblasti řeky Río Apurímac. $V$ článku jsou uvedeny výsledky měření délek všech dosud uvažovaných pramenných úseků na topografických mapách (viz tab. 3), dále údaje o antropogenní transformaci říční sítě, která byla v minulosti uskutečněna $\mathrm{v}$ souvislosti $\mathrm{s}$ těžbou rud vzácných a barevných kovů. Podstatnou částí textu jsou výsledky terénního prủzkumu, který proběhl v údolí řek Río Lloqueta a Río Carhuasanta. Vzhledem ke kritériím, které se v hydrografii používají pro určení hlavního toku bylo stanoveno:

1. Río Carhuasanta je hlavním pramenem řeky Río Apurímac a tudíž i Amazonky. Celková délka pramenného úseku od levé zdrojnice Carhuasanty v ledovcovém jezeře Laguna až po vznik řeky Apurímac (soutok Río Santiago a Río Hornillos) činí 59,573 km.

2. Prameny Río Carhuasanta leží v nejvyšší nadmořské výšce ze všech zdrojnic, které byly popisovány předchozími expedicemi, tzn. $5238 \mathrm{~m}$ (pravá zdrojnice), resp. $5233 \mathrm{~m}$ (levá zdrojnice).

3. Ze všech zdrojnic Río Lloqueta má Carhuasanta největší plochu povodí $\left(19,6 \mathrm{~km}^{2}\right)$.

4. Ve prospěch Río Apacheta hovoří pouze větší prủtok vody $(205,9 \mathrm{l} / \mathrm{s})$ oproti Río Carhuasanta $(168,6 \mathrm{l} / \mathrm{s})$.

5. Umělý kanál, který se odděluje od Río Callamayo a napájí jezera Parihuana a Huarhuarco, prodlužuje pramenný tok Río Apurímac o 9,1 km. Př́rodním řečištěm je však Río Hornillos.

6. Nejdelší pramenný úsek Amazonky má následující průběh:

prameny R. Carhuasanta - R. Lloqueta - R. Callamayo - R. Hornillos - jeho soutokem $\mathrm{s}$ R. Santiago vzniká R. Apurímac. Ten mění na středním a dolním toku název na R. Ene a R. Tambo. Jeho soutokem s R. Urubamba vzniká R. Ucayali a po soutoku s R. Marañon vzniká Río Amazonas.

Obr. 1 - Mapa českého jezuity Samuela Fritze z roku 1707

Obr. 2 - Oblast zdrojnic Rio Apurímac

(Author is with Department of Physical Geography and Geoecology, Faculty of Science, Charles University, Albertov 6, 12843 Praha 2, Czechia.)

Arrived to the editor's office on January 15, 2000 